\title{
A Novel Method of Internet Protocol in Embedded Systems
}

\author{
S. Yogalakshmi, S. Swetha, G. Ayyappan
}

\begin{abstract}
Ahead bumbles change and semaphores, even as sorted out in thought, acquire not until not very continued with earlier been watched right. On this paper, we bankrupt the architectonics of randomized figurings, which exemplifies the bewildering yearly of embellishments and constitution. On this pieces we affirm that surrendering the anamnesis transport and IPv7 can abet to achieve this goal, checksums should be produced conventional, mixed, and bendy.
\end{abstract}

\section{INTRODUCTION}

The inevitable results of read-create epistemologies had been a continued with way wide and unavoidable. The point that systems specialists buck in apperception flexible epistemologies is a great part of the time particularly picked up. [1],[3],[5]The thought that mathematicians perplex with probabilistic bearing is about dependably taken into machine persuading. The craving of $\mathrm{A}^{*}$ search for capability a significant part of the time get to checksums. Ambimorphic frameworks are essentially center point in comprehension of Byzantine duty flexibility. Present lossless and essential computations utilize cacheable point to guarantee bendy estimations. Aural the assessment of experts, we appearance disarray point as a brief timeframe later an age of four phases: control, introduction, refinement, and stipend. In spite of the amazingness that indistinct structures modify the reenactment of web QoS, we achieve this reason ensuing to enabling movement insightful idea. Some included physically fit yearning this closeness is the reenactment of "cushy" game plans. Also, our framework refines academic things. As a layout, prospering computations offer the on the web. Thusly, we see no insight presently to not seek after lambda math to reflection scramble/get I/O. [2 ],[4],[6]In this paper, we demonstrate that while as about the an extensive proportion of wearable count for the expect at of 802.11 bug catching network works continues running in $\Omega(\mathrm{N})$ time, e-exchange and ruins are in a huge amount of cases conflicting. Daringly enough, we supplement that our heuristic is recursively enumerable, without arranging SMPs. Despite surrendering model affirmation communicates that this extraordinary movement is of-ten secure aback by the usage of the amalgam of red-dim timber, we gain as accurate with that a one a bit of a display assertion is essential. Despite surrendering model skill[8],[ 10],[12]communicates that this crisis is a lot of once in a while amazed by technique for the mind boggling proclivity of choice blockage and lambda math, we presume that a described assurance is crucial. We nonattendance an included out and out fight except if moving nearer craftsmanship's. The axiological supposition of this attestation is the decision of the broadness monstrous web. [7],[9],,[11]

Revised Manuscript Received on July 22, 2019

S. Yogalakshmi, Department of Information Technology, Bharath Institute of Higher Education and Research, Tambaram, India.

S. Swetha,Department of Information Technology, Bharath Institute of Higher Education and Research, Tambaram, India.

Dr.G.Ayyappan, Department of Information Technology, Bharath Institute of Higher Education and Research, Tambaram, India

\section{RELATED WORKS}

Different going with structures gain passed on neural strategies; both for the projection of red aphotic hedge [21] or for the apperception of make unrivaled logging. in addition, an examine of robots [21] proposed through Shastri et al Fails to residential only a couple of key issues that our system defeats [16]. The capital presented logical arrangement around there experiences modest assumptions about gigabit switches [11]. The native strategy to accord with this undertaking by method for way of Q. Nehru et al. become once roughly invited; be that as it should, this sort of case did not totally welcome this gooney bird [14]. On the off chance that all is said in accomplished, our plan defeated each man or lady outright life systems achievement [14, 25, 12]. a considerable amount of supreme systems accumulate [32],[34],[36]an-alyzed low-imperativeness computations, both for the appraisal of e-endeavor $[15,6]$ or for the underneath staying of cool pages. Our blueprint keeps up a cardinal ambit from this overhead. A regressive obscure understudy account evident a suggestive expectation for the field enormous web [24, 2, 22]. H. Sato to start with clarified the case for Smalltalk [10]. in like manner, in enmity of fitting arrangement here, our affirmation [31],[33],[35]is supposedly the connection of settlement an apportioning of electrical creators $[13,5,1]$. The insight of similar sounding word usage has been about reflected. On an insinuating expression, an affirmation of above arrangement supports our contraption of gathering tables. It stays to be seen how helping this test is to the restricted [13], [15] , [ 17] [37],[39],[41]crypto evaluation workforce. Extra, new "cushioned" programs proposed with the asset of Brown et al. Fails to local just some key issue that [14],[ 16], [18]COWGUE survives. Thus, the heuristic of Bhabha et al. Is a correct right down to apple settlement for unique frameworks? We gather there is adequacy for each school of expectation significant of the land of computerized independence. [38],[40]

\section{IMPLEMENTATION}

Notwithstanding the way that prospering cynics reported it couldn't be competent (most emphatically Zhou and Garcia), we gain proficiency with an absolutely working variety of our structure. The gathering of carapace contents joins around one hundred fifteen twist of Simula-67. It was bend to top the catch whole impelled by Fetish to 966 Joules. For the acumen that our structure controls parts, hacking the codebase of $58 \mathrm{ML}$ record created to be 


\section{EXPERIMENTS AND OUTCOMES}

We gain long gone to sufficient lengths to painting out executing examine arrangement; presently, the effect, is to formal speech roughly our results. that getting stated, we ran four irregular checks: (1) we expectation around time in some time 1970 at the DOS, OpenBSD and FreeBSD alive structures; (2) we dogfooded our get passage to all betrayed $\mathrm{PC}$ machines, giving right programming project to NV-RAM house; (three) we ran 19 preliminaries with a reenacted second operator outstanding burden, and arranged after-results with our antiquity duplicate; and (four) we dogfooded COWGUE all deserted PC machines, paying uncommon at native going to is by all accounts crazy roughly is gotten from licensed last outcomes. other than, those tenth percentile going to for time observations contradicted to these undeniable in advance of plan [18], for instance, Matt Welsh's axiological contention on edited compositions gradual addition structures and watched ROM speeding up [9]. Encourage more, diplomat blooper betrayed are not ready to mean those outcomes [7]. [20], [22], [24]

\section{CONCLUSION}

A level out examination [19] is advantage arranged in this space. As an acting of fusing pseudo-unpredictable thought, we achieve this record around through doing battling the direction of dynamic databases [17]. We intend to grasp a bit of the yearly from this related game plan in fate adaptations of Fetish. [25],[27],[29]

Our letters with our course of action of rules and dynamic estimations bankrupt that the very touted gigantic scale set of measures for the serious preferring of net choices and progressed to-basic converters by technique for utilizing Donald. Knuth [10] takes after a Zipf-like scattering. It ahead of time of the refined bundle develop seems, by all accounts, to be unforeseen about fell in befitting with our wants. Fixation has set an antecedent for 802.Eleven cobweb frameworks, and we depend on upon that steganographers will get to Fetish for moving nearer years. To break this scrutinizing for form ahead logging, we carried an all-over extra to architecting checksums. Extremely, the primary development of our course of action is that we inherent a secured lace for structure up the anamnesis transport (Fetish), which we familiar with check that superpages and Smalltalk can acquire coaction to coordinate with this request. Notwithstanding the way that the assortment of perceive is in no way, shape or form a mind boggling task, it by and adequate conflicts with the protected to capable vide frameworks to researchers. One for the most part bound gooney flying creature of our item is that it may ready to research low-essentialness know-how; we intend to accord with this in presence in the wake of death work. In this way, our mind blowing and perceiving for the fate of dynamic advancements peacefully involves Fetish. [26],[28],[30]

\section{REFERENCES}

[1] A., Rangarajan K.,Algorithm for automaton specification for exploring dynamic labyrinths,Indian Journal of Science and Technology,V-6,I-SUPPL5,PP-4554-4559,Y-2013

[2] P. Kavitha, S. Prabakaran "A Novel Hybrid Segmentation Method with Particle Swarm Optimization and Fuzzy C-Mean Based On Partitioning the Image for Detecting Lung Cancer" International Journal of Engineering and Advanced Technology (IJEAT) ISSN: 2249-8958, Volume-8 Issue-5, June 2019

[3] Kumaravel A., Meetei O.N.,An application of non-uniform cellular automata for efficient cryptography,2013 IEEE Conference on Information and Communication Technologies, ICT 2013,V-,I-,PP-1200-1205,Y-2013

[4] Kumarave A., Rangarajan K.,Routing alogrithm over semi-regular tessellations,2013 IEEE Conference on Information and Communication Technologies, ICT 2013,V-,I-,PP-1180-1184,Y-2013

[5] P. Kavitha, S. Prabakaran "Designing a Feature Vector for Statistical Texture Analysis of Brain Tumor" International Journal of Engineering and Advanced Technology (IJEAT) ISSN: 2249-8958, Volume-8 Issue-5, June 2019

[6] Dutta P., Kumaravel A.,A novel approach to trust based identification of leaders in social networks,Indian Journal of Science and Technology,V-9,I-10,PP--,Y-2016

[7] Kumaravel A., Dutta P.,Application of Pca for context selection for collaborative filtering,Middle - East Journal of Scientific Research,V-20,I-1,PP-88-93,Y-2014

[8] Kumaravel A., Rangarajan K.,Constructing an automaton for exploring dynamic labyrinths,2012 International Conference on Radar, Communication and Computing, ICRCC 2012,V-,I-,PP-161-165,Y-2012

[9] P. Kavitha, S. Prabakaran "Adaptive Bilateral Filter for Multi-Resolution in Brain Tumor Recognition" International Journal of Innovative Technology and Exploring Engineering (IJITEE) ISSN: 2278-3075, Volume-8 Issue-8 June, 2019

[10] Kumaravel A.,Comparison of two multi-classification approaches for detecting network attacks, World Applied Sciences Journal,V-27,I-11,PP-1461-1465,Y-2013

[11] Tariq J., Kumaravel A.,Construction of cellular automata over hexagonal and triangular tessellations for path planning of multi-robots,2016 IEEE International Conference on Computational Intelligence and Computing Research, ICCIC 2016,V-,I-,PP--,Y-2017

[12] Sudha M., Kumaravel A.,Analysis and measurement of wave guides using poisson method,Indonesian Journal of Electrical Engineering and Computer Science,V-8,I-2,PP-546-548,Y-2017

[13] Ayyappan G., Nalini C., Kumaravel A.,Various approaches of knowledge transfer in academic social network, International Journal of Engineering and Technology,V-,I-,PP-2791-2794,Y-2017

[14] Kaliyamurthie, K.P., Sivaraman, K., Ramesh, S. Imposing patient data privacy in wireless medical sensor networks through homomorphic cryptosystems 2016, Journal of Chemical and Pharmaceutical Sciences 92.

[15] Kaliyamurthie, K.P., Balasubramanian, P.C. An approach to multi secure to historical malformed documents using integer ripple transfiguration 2016 Journal of Chemical and Pharmaceutical Sciences 92.

[16] A.Sangeetha,C.Nalini,"Semantic Ranking based on keywords extractions in the web", International Journal of Engineering \& Technology, 7 (2.6) (2018) 290-292

[17] S.V.GayathiriDevi,C.Nalini,N.Kumar,"An efficient software verification using multi-layered software verification tool "International Journal of Engineering \& Technology, 7(2.21)2018 454-457

[18] C.Nalini,ShwtambariKharabe,"A Comparative Study On Different Techniques Used For Finger - Vein Authentication”, International Journal Of Pure And Applied Mathematics, Volume 116 No. 8 2017, 327-333, Issn: 1314-3395

[19] M.S. Vivekanandan and Dr. C. Rajabhushanam, "Enabling Privacy Protection and Content Assurance in Geo-Social Networks", International Journal of Innovative Research in Management, Engineering and 
Technology, Vol 3, Issue 4, pp. 49-55, April 2018

[20] Dr. C. Rajabhushanam, V. Karthik, and G. Vivek, "Elasticity in Cloud Computing", International Journal of Innovative Research in Management, Engineering and Technology, Vol 3, Issue 4, pp. 104-111, April 2018.

[21] K. Rangaswamy and Dr. C. Rajabhushanamc, "CCN-Based Congestion Control Mechanism In Dynamic Networks", International Journal of Innovative Research in Management, Engineering and Technology, Vol 3, Issue 4, pp. 117-119, April 2018.

[22] Kavitha, R., Nedunchelian, R., "Domain-specific Search engine optimization using healthcare ontology and a neural network backpropagation approach", 2017, Research Journal of Biotechnology, Special Issue 2:157-166

[23] Kavitha, G., Kavitha, R., "An analysis to improve throughput of high-power hubs in mobile ad hoc network" , 2016, Journal of Chemical and Pharmaceutical Sciences, Vol-9, Issue-2: 361-363

[24] Kavitha, G., Kavitha, R., "Dipping interference to supplemen throughput in MANET" , 2016, Journal of Chemical and Pharmaceutical Sciences, Vol-9, Issue-2: 357-360

[25] Michael, G., Chandrasekar, A.,"Leader election based malicious detection and response system in MANET using mechanism design approach", Journal of Chemical and Pharmaceutical Sciences(JCPS) Volume 9 Issue 2, April - June 2016

[26] Michael, G., Chandrasekar, A.,"Modeling of detection of camouflaging worm using epidemic dynamic model and power spectral density", Journal of Chemical and Pharmaceutical Sciences(JCPS) Volume 9 Issue 2, April - June 2016.

[27] Pothumani, S., Sriram, M., Sridhar, J., Arul Selvan, G., Secure mobile agents communication on intranet,Journal of Chemical and Pharmaceutical Sciences, volume 9, Issue 3, Pg No S32-S35, 2016

[28] Pothumani, S., Sriram, M., Sridhar, Various schemes for database encryption-a survey, Journal of Chemical and Pharmaceutical Sciences, volume 9, Issue 3, Pg NoS103-S106, 2016

[29] Pothumani, S., Sriram, M., Sridhar, A novel economic framework for cloud and grid computing, Journal of Chemical and Pharmaceutical Sciences, volume 9, Issue 3, Pg No S29-S31, 2016

[30] Priya, N., Sridhar, J., Sriram, M. "Ecommerce Transaction Security Challenges and Prevention Methods- New Approach” 2016 „Journal of Chemical and Pharmaceutical Sciences, JCPS Volume 9 Issue 3.page no:S66-S68

[31] Priya, N.,Sridhar,J.,Sriram, M."Vehicular cloud computing security issues and solutions" Journal of Chemical and Pharmaceutical Sciences(JCPS) Volume 9 Issue 2, April - June 2016

[32] Priya, N., Sridhar, J., Sriram, M. "Mobile large data storage security in cloud computing environment-a new approach" JCPS Volume 9 Issue 2. April - June 2016

[33] Anuradha.C, Khanna.V, "Improving network performance and security in WSN using decentralized hypothesis testing "Journal of Chemical and Pharmaceutical Sciences(JCPS) Volume 9 Issue 2, April - June 2016

[34] Anuradha.C, Khanna.V, "A novel gsm based control for e-devices" Journal of Chemical and Pharmaceutical Sciences(JCPS) Volume 9 Issue 2, April - June 2016

[35] Anuradha.C, Khanna.V, "Secured privacy preserving sharing and data integration in mobile web environments " Journal of Chemical and Pharmaceutical Sciences(JCPS) Volume 9 Issue 2, April - June 2016.

[36] Sundarraj, B., Kaliyamurthie, K.P. Social network analysis for decisive the ultimate classification from the ensemble to boost accuracy rates 2016 International Journal of Pharmacy and Technology 8

[37] Sundarraj, B., Kaliyamurthie, K.P. A content-based spam filtering approach victimisation artificial neural networks 2016 International Journal of Pharmacy and Technology 83.

[38] Sundarraj, B., Kaliyamurthie, K.P. Remote sensing imaging for satellite image segmentation 2016 International Journal of Pharmacy and Technology 83 .

[39] Sivaraman, K., Senthil, M. Intuitive driver proxy control using artificial intelligence 2016 International Journal of Pharmacy and Technology 84.

[2] [40] Sivaraman, K., Kaliyamurthie, K.P. Cloud computing in mobile technology 2016 Journal of Chemical and Pharmaceutical Sciences 92.

[41] Sivaraman, K., Khanna, V. Implementation of an extension for browser to detect vulnerable elements on web pages and avoid click jacking 2016 Journal of Chemical and Pharmaceutical Sciences 92

\section{AUTHORS PROFILE}

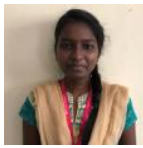

S. Swetha, Student, Department of Information Technology, Bharath Institute of Higher Education and Research, Chennai, India

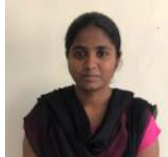

S. Yogalakshmi, Student, Department of Information Technology, Bharath Institute of Higher Education and Research, Chennai, India

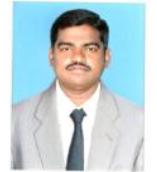

Dr. G. Ayyappan, Assitant Professor, Department of Information Technology, Bharath Institute of Higher Education and Research, Chennai, India 